UDC 81'253

DOI https://doi.org/10.32999/ksu2663-3426/2019-2-17

\title{
SIGHT TRANSLATION IN THE TRANSLATION TAXONOMY
}

\author{
Mykhailenko Valerii Vasylovych, \\ Doctor of Philology, \\ Professor of the Department of Translation and Philology \\ King Danylo University \\ valerymykhaylenko@i.ua \\ orcid.org/0000-0003-3263-7156
}

\begin{abstract}
This research has a twofold objective: finding some evidence of specific translation competence skills in translation tasks and comparing these data in sight translation and written translation in order to prove the sight translation. Two main assumptions are put forward: (1) the Sight Translation (henceforth, ST) is a complex process representing a three-act operation: (1) perception of the written text; (2) transformation; (3) oral reproduction. Step (2) has a restriction "retaining the content". (2) The translator's activity reveals another function in the specific setting, that of a "mediator" between either two parties of experts, for instance, at the negotiation, or in the court room - amid the trial party and the defendant, or betwixt the doctor and the patient in the hospital, or the architect and the construction worker, the designer and the executor at the enterprise, etc. Accordingly, ST differs from interpreting (see Dragsted, 2007:251) (consecutive and simultenous (Ivanova, 2019:27; cf: Song, 2010:120) in Step (1). It differs from the consecutive interpreting in timing the reproduction - simultaneity : sequence (Step 3). It differs from the simultaneous interpreting in its type of the target recipient (Step 3) - it needs specification: expert or layman. We shall start considering the ST definition with the background notion of translation proposed by Lawrence Venuti as "a process by which the chain of signifiers that constitutes the source-language text is replaced by a chain of signifiers in the target language (Venuti, 2004:15). The term ST can refer to different types of activity, depending on the conditions under which the ST is performed. Firstly, one may distinguish between ST with and without preparation of the text, called "unstressful ST" and "stressful ST", respectively. Secondly, the literature on ST also distinguishes between ST and SI (sight interpreting) (Lambert, 2004:298). The overview of the ST research and a critical analysis of current publications are by no means exhaustive, but they reveal the major trends of the ST development.
\end{abstract}

Key words: concept of translation, competence, algorithm of sight translation, intra- and inter-relatioship, professional discourse, integrity.

\section{ПЕРЕКЛАД 3 АРКУША В ТАКСОНОМІї ПЕРЕКЛАДУ}

\author{
Михайленко Валерій Васильович, \\ доктор фрілологічних наук, \\ профресор кафедри перекладу та фрілології \\ Університет Короля Данила \\ valerymykhaylenko@i.ua \\ orcid.org/0000-0003-3263-7156
}

Це дослідження має двояку мету: визначити певну специфіку перекладацької компетенції для подальшого їі порівняння з компетенцією перекладу з аркуша. Запропоновано два основні припущення: (1) переклад з аркуша (ПА) $\epsilon$ складним процесом, що являє операцію з трьох дій: (1) сприйняття письмового тексту; (2) трансорормація; (3) усне відтворення. Крок (2) має обмеження - «збереження змісту». (2) Діяльність перекладача актуалізує додаткову функцію в конкретному контексті, як наприклад, «посередника» між двома сторонами експертів, наприклад, на перемовинах, або у залі судових засідань - серед учасників судового засідання та обвинуваченим, або між лікарем і пацієнтом у лікарні, або архітектором і будівельником тощо. Відповідно, ПА вирізняється від усного перекладу своєю послідовністю та одночасністю (крок 1). ПА вирізняється від послідовного перекладу часом відтворення одночасність : послідовність (Крок 2). Він також вирізняється від синхронного перекладу типом реципієнта інформації (Крок 3), який потребує уточнення: спеціаліст : неспеціаліст. Розглянемо визначення ПА у рамках основного поняття перекладу, запропонованого L. Venuti (2004), як «процесу, за допомогою якого ланцюжок позначень, що становлять текст мови ориеіналу, замінюється на ланцюжок означень мовою перекладу. Термін ПА може належати до різних видів діяльності, залежно від умов, за яких виконується ПА. По-перше, можна розрізняти ПА як з попереднім опрацюванням тексту оригіналу, так і без попереднього опрацювання, по-друге, у літературі з ПА також розрізняють «переклад з аркуша (класичний)» та ПУ «усний переклад з аркуша». Оәляд публікацій з ПА та проведене дослідження ніяк не є вичерпними, але вони накреслюють основні тенденції розвитку ПА як окремого виду перекладацької діяльності. Необхідні додаткові дослідження ST, щоб підтвердити або відкинути наші припущення, що розвиваються на терені у межах корпусного аналізу, практики комп'ютерної лексикографії для підготовки електронних двомовних глосаріїв і тезаурусів для перекладачів у різних галузях науки та техніки. Також потрібні дослідження у галузі підготовки просресійних багатопроффільних перекладачів.

Ключові слова: концепт перекладу, компетенція, алгоритм перекладу з аркуша, інтра- та екстравідношення, професійний дискурс, цілісність. 


\section{Introduction}

The numerous studies in the area of translation/interpreting helped us to put forward: First, the Sight Translation (henceforth, ST) is a complex process representing a three-act operation: (1) perception of the written text; (2) transformation; (3) oral reproduction. Step (2) has a restriction "retaining the content". Second, the translator's activity reveals another function in the specific setting, that of a "mediator" between either two parties of experts, for instance, at the negotiation, or in the court room - amid the trial party and the defendant, or between the doctor and the patient in the hospital, or the architect and the construction worker, the designer and the executor at the enterprise, etc.

Accordingly, ST differs from interpreting (see Dragsted, 2007:251) (consecutive and simultaneous (Ivanova, 2019:27; cf: Song, 2010:120) in Step (1). It differs from the consecutive interpreting in timing the reproduction - simultaneity : sequence (Step 3). It differs from the simultaneous interpreting in its type of the target recipient (Step 3) - it needs specification: expert or layman, for instance, "it is vital that the court interpreter provides a complete and accurate sight translation of the document so the accused can understand the conditions imposed by the judge" (see The Ministry of the Attorney General, Ontario). In case of the layman as a receptor the ST interpreter must actualize the function of a "cross-cultural mediator". The functions the translator/interpreter have been radically reconsidered. Lawrence Venuti and later Susana Bassett and André Lefevere wrote on a "cultural turn" in translation studies and explored the history of translation in the Anglo-American world, arguing that the illusion of fluency -i.e. creating the impression that a text has not actually been translated at all -marginalizes translation and effectively renders translators invisible. They point out that the illusion of transparency "conceals the numerous conditions under which a translation is made, starting with the translator's crucial intervention in the foreign text" (Bassett, 2011).

Lawrence Venuti points out that "the growth of translation studies as a separate discipline is a success story of the 1980s" (Venuti 2004: vii). Thanks to the communities of expertise and world economy ST has come into prominence as an instrument to gain access to the information encoded in a foreign language text (see Bassnett, 2011). Thence the ST definition as an autonomous branch located between Translation and Interpreting in the Translation taxonomy needs clarifying.

Traditionally, ST used to be defined as the oral translation of a written text: the source text is a written text as in written translation, while the target text is an oral text as in interpreting in various settings (cf: Chen, 2015). This is a special mode of simultaneous interpreting (henceforth, SI), which is termed "simultaneous interpreting with text" (cf: Viaggio, 1995: 45; Lee, 2012: 695]. One can note the overlapping of (written) translation and (oral) interpreting. Additionally, rapid development of immigration and international institutions of justice require the Court Interpreting as a type of ST has been recently drawing an increasing level of attention in a variety of disciplines, including legal science, applied linguistics, and translation studies. $\mathrm{Cf}$ the statistics of the job market for various types of translators and interpreters, which have become ubiquitousin different spheres of the US life.

Employment of interpreters and translators is expected to grow 42 percent from 2010 to 2020, much faster than the average for all occupations. In particular, job opportunities should be plentiful for interpreters and translators specializing in healthcare and law, because of the critical need for all parties to fully understand that information (U.S. Department of Labor 2012). The following investigation presents the state-of-the-art of the sight translation status in the translation taxonomy.

\section{Definitional analysis}

We shall start considering the ST definition with the background notion of translation proposed by Lawrence Venutias: "a process by which the chain of signifiers that constitutes the source-language text is replaced by a chain of signifiers in the target language, which the translator provides on the strength of interpreting (Venuti, 2004: 15).

(1) The most popular definition of ST is the reading of a text by the interpreter from the SL into the TL, simultaneously, in a manner in which the content of the document can be easily understood by the professionals. In our view it rather vague where interpreting is a part of the generalized "reading" which must be including three acts: reading, transforming, and reproducing.

(2) Sight translation is often considered to be a step that comes before simultaneous interpretation. Then ST seems to be an initial stage in the Simultaneous Interpreting track of training interpreters.

(3) Sight translation transforms a written message into a spoken message. It involves reading a text silently in the source language, and then speaking it in the target language (see The Ministry of the Attorney General, Ontario). Here the component of simultaneity of reading and interpreting is mentioned

(4) Olga Krapivka says that sight translation is often mentioned in relation to court interpreter training. In fact, ST is just as difficult as simultaneous interpretation, and involves some of the 
same mental processing: the input is visual (the written word) rather than oral (the spoken word) (Krapivka, 2018: 695), but the interpreter still has to process a thought in the Source Language and generate the Target Language version of that thought.

(5) Sight translation means the oral translation of a written document, a hybrid of translation and interpretation (Gonzalez, 2012: 895), often known as "sight interpretation". Here the term interpreting substitutes the term translation Jiménez Ivars points out the lack of agreement on what to call this form of translation and how it should be defined (Ivars, 2008: 79-80). After reviewing a number of definitions proposed by scholars over the years, the author arrived at the following definition: sight translation consists of the oral reformulation in the target language of a text written in the source language for at least one recipient; this recipient may be a listener who shares the communicative situation with the translator, or a reader who will later read a written transcript of the oral reformulation carried out by the translator (Ivars, 2008: 79). The type of recipient is underlined - his/her sharing the common knowledge of the content with the author - each in their own languages. Xiangdong Li expresses his "industrial" approach to ST, which he links with three forms of translation: dictated translation, recorded translation, ST, and speech recognition technology unification due to the same nature, at the same time he stresses the importance of ST which "should be taught as an itself' (Li, 2014: 67-68).

2.2. ST as a Form of Professional Practice in the T\&Industry

Sight translation is a quicker way of translating, especially when an interpreter is already on site for an assignment. It helps both the client and the professional tremendously, and is incredibly demanding for the interpreter, as it is a combination of both translation, formal transformation and contensive interpreting. However, we must take into consideration that not all translators and interpreters are well read in the professional discourse they have to translate (see Felberg, 2017: 23) the fruit of their interpreting won't meet the demands of the client or customer.

\section{Current issues of sight translation}

In spite of its importance in both interpreting contexts and interpreting training, sight translation and its role in interpreting/translation has not enjoyed an overhauling investigation among other modes of interpreting (Akbari, 2017: 24; Vargas, 2019: 2). Holly Mikkelson stresses that ST has been always treated as one of the functions performed and the public service interpreters should acquire a list of "knowledge, skills and abilities from various areas of human endeavours before starting a career" (Mikkelson, 2014: 9). But ST requires rapid text analysis while reading, rapid conversing information from one language to another avoiding word for word translation, and masterfully employing public speaking techniques (Lee, 2012: 695). Reading may be self-paced, but "ST delivery speed may not been entirely at the discretion of the interpreter" (Brady 1989: 142). Sight translation is sometimes called sight interpreting, underlining the oral target-text presentation. According to M. Agrifoglio and some other scholars sight translation have been treated as a type of simultaneous interpreting or a special type of use of a written text in interpreting (Agrifoglio, 2004: 43). Sight translation has mostly been considered as a supportive interpretation method for simultaneous and consecutive interpretation or just a pedagogical exercise for getting started in the techniques of consecutive interpreting and simultaneous interpreting, an exercise by which interpreter trainees can learn to react quickly and improve their oral skills (Weber, 1990).

Recent developments in many fields such as international relations, business, world trade, social sciences, and technology and the need for accessing to information in the shortest possible time necessitate the ST growth to an active and efficient communication medium. Translation, notably interpretation, is one of those communication media. The term "interpretation" generally brings to mind simultaneous, consecutive or liaison kinds of interpretation to mind. No doubt, sight translation, when performed without previous reading, may be considered by some authors to be closer to interpreting than to written translation both because of the immediacy that imposes strict time restrictions and the oral nature of the task (Jiménez Ivars, 2001, 2008; Agrifoglio, 2003; 2004).

However, sight translation, consecutive interpreting and simultaneous interpreting are performed under different conditions. Even though there are similarities in the mental process, the overall process is different. In sight translation, the translator reads a written text, whereas the interpreter, in both consecutive and the simultaneous modes, listens to a speaker. Due to the differences in the process, the methods and strategies that an interpreter trainee uses in sight translation will change (Felberg, 2017: 232). The term ST can refer to different types of activity, depending on the conditions under which the ST is performed. Firstly, one may distinguish between ST with and without preparation of the text, called "unstressful ST" and "stressful ST", respectively. Secondly, the literature on ST also distinguishes between ST and SI (sight interpreting) (Lambert, 2004: 298). 


\section{Sight translation competence}

Jiménez Ivars defines translation competence (cf: Schwieter, 2014; see also interpreting competence: Kalina, 2000: 3) as the ability to carry out the transfer process from the Source Text to the production of the Target Text for the receptor's needs and the purpose of the translation (2003: 57-59). We shall employ the term "intelligence" (Gardner, 2010) for the constituents of the Translation competence model instead of the sub-competence proposed by the Pacte Group "Procés d'Adquisició de la Competència Traductorai Avaluació" (see Albir, 2017: 3-34): Bilingual intelligence is a procedural knowledge needed to communicate in two languages which also includes the ability to control language interferences.

Extralinguistic intelligence is a declarative knowledge about the world in general and special areas covering bicultural, encyclopadic, and subject knowledge. Translation intelligence is a declarative knowledge, both implicit and explicit. Instrumental intelligence is a procedural knowledge related to professional practice. Psycho-physiological intelligence is a part of expert knowledge including different types of cognitive and attitudinal components and psycho-motor mechanisms (see Lorscher, 1991).

Strategic intelligence is planning the translation process, assessing it, activating the different intelligences, it identifies translation problems and applies procedures to solve them. Cross-cultural intelligence is transmission of values and beliefs. Susan Bassnett writes that "some authors have gone so far as to suggest that translation is a common human condition in the new millennium, with people "translating" from one culture to another" (Bassnett, 2011). Actually, it is quite true, one can observe at a family reunion when relatives of three or four generations try to exchange their views using translation or rather interpreting as an efficient instrument.

The main concern for the sight translator is to keep to the source text content avoiding his/her individual mode. However, in case of the receptor's misunderstanding the writer's intention or the national values referred to the translator must fill in the gap to help the receptor fully comprehend the content. The choice of cultural strategy may result in source-culture bound translation (the translation stays within the source language culture - so called foreignisation), target-culture bound translation (the translation stays within the target language culture - so called domestication) or in a "hybrid", where the translation is a product of a compromise between two or more cultures (Ginter, 2002: 1650;
Treguer, 2017: 137; Mykhaylenko, 2018: 63; Vargas-Urpi, 2019: 1-3).

Let's consider the multinational corporation where all the referred intelligences are actual for various types of translators and interpreters, but primarily for sight translators dealing with (1) paper-work, (2) employers, and (3) employees speaking different languages. It is nowadays the most commonly used form in environments such as courtroom, education, healthcare, customs, police, public administration, or other settings (Lee, 2002: 695; Cenkova 2015: 374; Šarčević, 2016; Yaling, 2012: 319; Vagras, 2019: 2). There the ST translator can expect users (clients) to ask questions to ensure they understand the information. Naturally, ST is thus a dyadicor a triadic communication, but in all the settings of ST the printed text is first.

\section{Challenges to sight translator/interpreter}

The lay public often assumes that language professionals are able to perform a number of language functions (or tasks or services). On the contrary, different language functions require different types of language skill training to be best honed through practice. ST as any other type of translation/interpreting requires similar skills such as a good memory, the ability to analyze meaning, and knowledge of terminology, each also relies on different skills within the four domains of language listening, speaking, reading, and writing.

Evidently, the high quality of ST can be based primarily on reading technique, reading comprehension, semantic mapping of the text, its restructuring in accordance with the TL rules and verbal presentation of the processed fragment. As one can see it is only an explicit part of the sight translator's competence (see Gile, 1991: 153), the major body or volume of his/her competence is implicit - the public language-in-use and specializing in professional discourses.

While interpreting/translation tend to occur in different settings and contexts, there is a danger of their overlapping: interference of the printed Source Language text, especially, English word order impact upon the Target (Ukrainian) Language oral interpreting, and foreignizing the Ukrainian terminological items due to the difference in professional discourse lexis.

The overview of the ST research in general and more specifically, for instance courtroom, interpreting is by no means exhaustive, but it attempts to discover the major trends on the topic, which has always been closely related to the translator/interpreter training and various settings of their activities.

\section{Conclusions}

This article provides an analysis of the current state-of-the art in the ST theory and practice and 
it also is aimed at raising some of the important sight translation issues - definition, status, internal (in translation taxonomy) and external (inter-disciplinary) relationships. More research into ST is needed in order to confirm or reject our assumptions evolving the corpora analysis and compiling electronic bilingual dictionaries and thesauri for the translators and interpreters in various areas of science and technology. Studies in professional public service interpreting are also needed.

\section{BIBLIOGRAPHY:}

1. D'Hayer Danielle. Public service interpreting and translation: Moving towards a (virtual) community of practice. Meta. 2012. Vol. 57. No1. P. 235-247.

2. Dragsted B., Hansen I.G. Exploring translation and interpreting hybrids: The case of sight translation. Meta. 2009. Vol. 54. No. 3. P. 588-604.

3. Frash S.S., Maksyutina O.V. Sight Translation as an Independent Branch of Translation. Вестник ТГПУ. 2010. Vol. 4. 76-81.

4. Gardner Howard. Multiple intelligences. 2010. http://www. howardgardner.com/MI/mi.html (Last accessed: 05/01/19).

5. Gile Daniel. Conference interpreting as a cognitive management problem. / Ed. Joseph H. Danks, Gregory M. Shreve, Stephen B. Fountain, Michael K. McBeath. Cognitive processes in translation and interpreting. Thousand Oaks, CA: Sage Press, 1997. Pp. 196-214.

6. Goldberg Joseph H., Wichansky Anna M. Eye tracking in usability evaluation: A practitioner's guide. / Ed. Jukka Hyönä, Ralph Radach, Heiner Deubel. The mind's eye: Cognitive and applied aspects of eye movement research. Amsterdam : Elsevier, 2003. Pp. 493-516.

7. Hale S. Community interpreting / Ed. F. Pöchhacker. The Routledge Encyclopedia of Interpreting Studies. Abingdon : Routledge, 2015. Pp. 65-69.

8. Hale S., Gonzalez Garcia E. Teaching legal interpreting at university level: A research-based approach. / Ed. L. Cirillo, N. Niemants. Teaching dialogue interpreting research-based proposals for higher education. Amsterdam /Philadelphia : John Benjamins, 2017. Pp. 199-216.

9. Hale S.B. Public service interpreting / The Oxford Handbook of Translation Studies. 2012. URL: http://dx.doi. org/10.1093/oxfordhb/9780199239306.013.0024 (Last accessed: 05/01/19).

10. Hong S. Paraphrasing as an anti-interference technique in sight translation. Interpreting and Translation Studies. 2010. Vol. 13. No. 2. Pp. 141-170.

11. Jakobsen Arnt L. Orientation, segmentation, and revision in translation / Ed. Glyde Hansen. Empirical translation studies: Process and product. Copenhagen studies in language. 27. Copenhagen : Samfundslitteratur, 2002. Pp. 191-204.

12. Jensen Kristian. Distribution of attention between source text and target text during translation / Ed. Sharon O'Brien. Cognitive explorations of Translation. London : Continuum, 2011. Pp. 215-236.

13. Kohn Kurt, Kalina Silvia. The strategic dimension of interpreting. Meta. 1996. Vol. 41(1). Pp. 118-38.
14. Mikkelson Holly. The interpreter's companion. Spreckels, CA: Acebo,1993. (CD-ROM edition).

15. Mikkelson Holly. The Interpreter's Edge. Spreckels, CA: Acebo, 1995. 325 p.

16. Muñoz Martín, Ricardo. On paradigms and cognitive translatology / Ed. Gregory M. Shreve and Erik Angelone. Translation and cognition. Amsterdam : John Benjamins, 2010. P. 169-187.

17. Mykhaylenko V.V. Glossary of Linguistics and Translation Studies: English-Ukrainian. Chernivtsi : Tehnodruk, 2015. 555 p.

18. Mykhaylenko V.V. Sight translation: Training algorithm /. Науковий журнал Львівського державного університету безпеки життєдіяльності «Львівський філологічний часопис»: зб. наук. праць. № 1. Львів, 2017. C. 49-54.

19. Mykhaylenko V.V. Sight translation in cross-cultural communication. Держава та регіони. Серія: Гуманітарні науки. № 2. (53) Запоріжжя : Класичний приватний університет, 2018. С. 63-68.

20. Mykhaylenko V.V. Meronymy in professional discourse translation / Ed. С.М. Єнікєєва. Нова фрілологія. Зб. наук. пр. Запоріжжя : ЗНУ, 2018. № 73. C. 82-88. DOI: https:// doi.org/10.26661 (Last accessed: 05/01/19).

21. Mykhaylenko Valery. Internationalisms in cross-cultural communication. Наукові записки Національного університету «Острозька академія»: серія «Філологія». Острог : Вид-во НаУОА, 2018. Вип. 1 (69), ч. 2. С. 25-28. DOI: 10.25264/25192558-2018-1(69)/2-25-28 (Last accessed: 05/01/19).

22. Ondelli Stefano. Medium shift in interpretation: Do interpreters produce oral texts? The Interpreters' Newsletter. 1998. Vol. 8. Pp. 181-193.

23. Pym Anthony. Redefining translation competence in an electronic age. In defence of a minimalist approach. Meta. 2003. Vol. 48(4). Pp. 481-97.

24. Risku Hanna. A Cognitive scientific view on technical communication and translation: Do embodiment and situatedness really make a difference? Target. 2010. Vol. 22(1). Pp. 94-111.

25. Šarčević S. New approach to legal translation. The Hague; Boston : Kluwer Law International, 2016. xiii, 308 pp.

26. Seeber Kilian G. Cognitive load in simultaneous interpreting. Existing theories - New Models. Interpreting. 2011. Vol. 13(2). Pp. 176-204.

27. Shreve Gregory M., Lacruz Isabel, Angelone Erik. Cognitive effort, syntactic disruption and visual interference in a sight translation task. / Ed. G.M. Shreve, E. Angelone. Translation and Cognition. American Translators Association Scholarly Monograph Series XV. Amsterdam/ Philadelphia : John Benjamins, 2010. Pp. 63-84.

28. Song S.Z. Skill transfer from sight translation to simultaneous interpreting. International Journal of Interpreter Education. 2010. Vol. 2. Pp. 120-134.

29. Viaggioт S. The praise of sight translation. The Interpreters' Newsletter. 1995. Vol. 9. Pp. 33-42.

30. Viezzi Maurizio. Information retention as a parameter for the comparison of sight translation and simultaneous interpretation: An experimental study. The Interpreters' Newsletter. 1989. No. 2. Pp. 65-69.

31. Valencia Virginia. Note-taking manual: A Study guide for interpreters and everyone who takes notes. Columbia, MD : Create Space Independent Publishing Platform, 2014. 123 p. 
32. Weber W.K. Training translators and conference interpreters. Orlando : Harcourt Brace Jovanovich International, 1984. $74 \mathrm{p}$.

\section{REFERENCES:}

1. Agrifoglio, Marjorie. (2004). Sight translation and interpreting. A comparative analysis of constraints and failures. Interpreting. Vol.6. Issue 1. P. 43-67.

2. Akbari, Alireza. (2017). Needed skills and strategies to improve the efficiency of sight translation in classroom context. Trans-kom. 2017. Vol. 10(1). P. 22-44.

3. AlbirAmparo, Hurtado. (2017). Translation and translation competence / Ed. A.H. Albir. Researching translation competence. Amsterdam. Philadelphia : Benjamins. P. 3-34.

4. Bassnett, Susan. (2017). The Translator ascrosscultural mediator. Oxford Handbooks Online. Retrieved from: https://www.oxfordhandbooks.com/.../oxfordhb/.../ oxfordhb-9780199239306-e-008 (Access: 04/30/19).

5. Brady, M. (1989). Case studies in sight translation / Ed J. Dodds. Aspects of English. Udine : Campanotto, 1989. P. 141-243.

6. Cenkova, I. (2015). Sight interpreting/translation / Ed F. Pöchhacker. Routledge Encyclopedia of Interpreting Studies. Abingdon : Routledge. P. 374-375.

7. Chen, Wallace. Sight translation. (2015). The Routledge Handbook of Interpreting. London/NewYork : Routledge. $468 \mathrm{p}$.

8. Dragsted, Barbara, Hansen, Inge G. (2007). Speaking your translation: Exploiting synergies between translation and interpreting / Ed. Franz Pöchhacker, Arnt L. Jakobsen, Inger M. Mees. Interpreting studies and beyond. Copenhagen Studies in Language. 35. Frederiksberg : Samfundslitteratur Press. P. 251-274.

9. Felberg, Tatjana R., Nilsen, Anne Birgitta. (2017). Exploring semiotic resources in sight translation. The Journal of Specialized Translation. Issue 18. P. 230-248.

10. Gile, D. (1995). Basic concepts and models for interpreter and translator training. Amsterdam : John Benjamins, 270 p.

11. Ginter, Anna. (2002). Cultural issues in translation. Studies about languages. No. 3. P. 1648-2824.

12. Gonzalez, Roseann Dueñas et al. (2012). Fundamentals of court interpretation: Theory, policy, and practice. Durham, North Carolina : Carolina Academic Press. Ixxii, 1539 pp.

13. Ivanova, Adelina. (2019). Use of retrospection in research on simultaneous interpreting / Ed. S. Tirkonen-Condit. Tapping and mapping the processes of translation and interpreting outlook on empirical research. Amsterdam/ Philadelphia : John Benjamins. P. 27-52.

14. Ivars, Jiménez. (2008). Sight translation and written translation. A comparative analysis of causes of problems, strategies and translation errors within the PACTE Translation competence model. FORUM. Revue international ed'interprétation et de traduction/InternationalJournalofInterpretationandTranslation. Vol 6. Issue 2. P. 79-104.

15. Kalina, Silvia. (2000). Interpreting competences as a basis and a goal for teaching interpreters. Newsletter. Vol. 10. P. 3-32.
16. Krapivkina, Olga. (2018). Sight translation and its status in training of interpreters and translators. Indonesian Journal of Applied Linguistics. Vol. 7. No. 3. P. 695-704.

17. Lambert, Sylvia. (2004). Shared attention during sight translation. Sight interpretation and simultaneous interpretation. Meta. Vol. 49, No 2, P. 221-458.

18. Lee, Jieun. (2012). What skills do student interpreters need to learn sight translation training? Meta. Vol. 57. No 3. P. 693-714.

19. Li, Xiangdong. (2014). Sight translation as a topic in interpreting research: Progress, problems and prospects. Across Languages and Cultures. Vol. 15(1). P. 67-89.

20. Lörscher, Wolfgang. (2001). Translation performance, translation process, and translation strategies. A psycholinguistic investigation. Tübingen : GunterNarr. $307 \mathrm{p}$.

21. Mikkelson, Holly M. (2014). Evolution of public service interpreter training in the U.S. FITTIS pos Iternational Journal. Vol. 1. P. 9-22.

22. Mykhaylenko, V.V. (2018). Sight translation in cross-cultural communication. Derzhava ta regioni. Seriya Humanitarni nauki. № 2 (53). C. 63-68.

23. Šarčević, S. (2016). Language and culture in EU law: Multi disciplinary perspectives. London, New York : Routledge. $270 p$.

24. Schwieter, John W., Ferreira, Aline. (2014). The development of translation competence: theories and methodologies from psycholinguistics and cognitive science. Cambridge : Cambridge Scholars Publishing. 328p.

25. Song, Hongwei. (2010). Skill transfer from sight translation to simultaneous interpreting: A Case study of an effective teaching technique. International Journal of Interpreting: Education. Vol. 2. P. 120-134.

26. Treguer-Felten, Genevieve. (2017). The role of translation in the cross-cultural transferability of corporate codes of conduct. International Journal of Cross Cultural Management. Vol. 17(1). P. 137-149.

27. Vargas-Urpi, Mireia. (2019). Sight translation in public service interpreting: a dyadic or triadic exchange? The Interpreter ad Translator Trainer. Vol. 13. P. 1-17.

28. Venuti, Lawrence. (2014). The translator's invisibility. London, New York : Routledge. 366 p.

29. Viaggio, S. (1995). The praise of sight translation and squeezing the last drop thereout of. The Interpreters' Newsletter. Vol. 4. P. 45-58.

30. Viezzi, Mario. (1990). Sight translation, simultaneous interpretation and information retention / Ed. L. Gran \& C. Taylor. Aspects of applied and experimental research on conference interpretation. Udine : Campanotto, P. 54-60.

31. Weber, Wilhelm K. (1990). The importance of sight translation in an interpreting program / Ed. David Bowen, Margareta Bowen. Interpreting yesterday, today, and tomorrow. Amsterdam/Philadelphia : John Benjamins Publishing. P. 44-52.

32. Yaling, Chen. (2017). Court sight translation from text-linguistic approach. Journal of Literature and Art Studies. Vol. 7. No. 3. P. 319-331.

Стаття надійшла до редакиї 25.07.2019. The article was received 25 July 2019 